\title{
IMPACTS OF LOCAL CHARACTERISTICS ON REGIONAL FDI INFLOWS INTO MEKONG DELTA
}

\author{
Nguyen Kim Phuoc ${ }^{1, *}$ \\ ${ }^{1}$ Ho Chi Minh City Open University, Vietnam. \\ *Email: phuoc.nk@ou.edu.vn
}

(Received: April 04, 2016; Revised: May 07, 2016; Accepted: May 17, 2016)

\begin{abstract}
The study used theory from Keynes (1936), Dunning (1981), Heckscher \& Ohlin (1991) on the movement of capital and foreign investment in previous studies, which are related to FDI to platform scientific research proposed model. GMM regression methods were used to determine the impacts of the 15 independent variables (including 6 variables representative for local characteristics) to FDI inflows (the dependent variable) in the Mekong Delta. Results found 9/15 variables affecting FDI flow into the Mekong Delta, which has 3 variables representing local characteristics: Regular expenses, freight volume by water and by land. Based on the results of research and local characteristics, some recommendations are proposed to attract FDI into more Mekong Delta.
\end{abstract}

Keywords: Foreign Direct Investment (FDI); Mekong Delta; local characteristics; General Method of Moments (GMM).

\section{Introduction}

Foreign direct investment (FDI) is an important element of the global economy and is a part of the economic development strategies of the developed and developing countries. UNCTAD (2014) identified in the near future, FDI inflow tends to shift to countries with good investment policy, the countries with good economic growth, the local call for interesting investment policy. This opens up a good opportunity for Vietnam in the process of attracting FDI. However, FDI flows into Vietnam without equitable distribution among provinces/cities nationwide.

According to the Ministry of Planning and Investment (2013), the bulk of FDI is concentrated in regions with favorable conditions, the economic centers and the largest cities. The remaining areas, especially the mountainous, remote areas which are characterized by geographical, economic infrastructure - underdeveloped society, are difficult to attract FDI, including Mekong Delta. According to $\mathrm{Vu}$ (2008) said, FDI investment in the country will depend on the characteristics of the receiving more investment or otherwise depending on the advantages of each locality, so no FDI allocation uneven across regions / countries 1 in the same domain. The question is the factor of local characteristics that affects FDI or not. Research "local characteristics affecting FDI flow into the Mekong Delta" aims is to find out the factors peculiar local impact in attracting FDI into the Mekong Delta, which proposed the solution helps attract FDI in Mekong Delta more, contributing to the economic growth of the Mekong Delta. Research content includes: Part 2: Theoretical Foundations; Part 3: Model of research; Part 
4: Data and research methods; Part 5: Results of study and Part 6: Conclusion and policy recommendations.

\section{Theoretical Foundations}

\subsection{Theory}

According Buthe \& Miller (2008), FDI is funds transferred from the parent company abroad to other countries to build a branch or business establishment. Directly Investments is long term ownership business establishments or plants abroad, other than indirect investments means ownership of financial assets.

Theory moving international capital investment of Lipsey (2001), said that FDI inflows are the most important international investment flows, especially for developing countries. Developed countries invested surplus by lower marginal productivity of developing countries, so there is a movement of capital from developed countries to developing countries or less developed. According to Kiyoshi Kojima (1973), moving international capital is due to the difference in margins between countries, this difference stems from differences in comparative advantage in the international division of labor fall. This is the background of the international economic activity, move the international production resources. Kyoshi Kojima (2010) said that FDI investment focus on countries that do not have the advantage of high technology, the relative lack of capital.

The theory of international investment options based on the advantage (in theory Zhejiang Chinese): According to Dunning (1981) investors investment options based on 3 factors O - L - I (Advantage of ownership (Ownership Advantages - advantages O), location advantage (Locational advantages advantages L) and the advantage of local goods (Internalisation advantages advantages I). The aforementioned three conditions must be satisfied before FDI, which mean to attract FDI, the conditions need to be achieved. Dunning (1981) said that the factors that "push" is derived from the advantages $\mathrm{O}$ and $\mathrm{I}$, and the advantage factor L create "pull" for FDI. However, these advantages fluctuate over time, space and the development of each country in each period, each area as well as the development and movement of FDI inflows. Dunning (1981) also said that the advantage of location (Locational Advantages - L) is reflected by factors such as: natural resources, the size of the economy, the quality of human resources, the size and growth of the market, infrastructure, wages and labor force, ...

According to Nowbutsing (2009), FDI has an impact on economic growth as the form of a direct impact. In addition, FDI also has an indirect effect on other factors and is subject to the impact of FDI back (reactive) from economic growth (GDP). Nowbutsing (2009) said that FDI and GDP have a relationship through the impact: direct, indirect (spreading) and feedback. FDI feedbacks from affected economic growth, if economic growth is affected by increased FDI gravity of profit, distribution and consumption capacity, ... of the economy, it will make FDI flows into countries much more.

According to Heckscher \& Ohlin (1991), the movement of foreign capital is determined through the ratio of the different inputs (the main factors such as capital, technology, labor). International investment capital tends to move from the surplus to the deficit, from countries with low marginal productivity of capital to where the marginal productivity of capital higher. The international investment funds are beneficial for both two countries (Kyoshi Kojima (2010)).

According to Nguyen Minh Sang (2011), Mekong Delta has many advantages due to specific characteristics such as geographical location, water resources, land resources, labor, young population, ... In particular, ships and roads transportation, in which 
geographical location is important in economic trade with other regions and neighboring countries.

\subsection{The factors affecting FDI}

Oshikoya (1994) said that if the increase of public investment mainly invests in social infrastructure, it will be factors promoting private investment. However, excessive increase public investment can boost private investment crowds out investment and public investment will be the burden of government debt in the future (Ghura \& Goodwin (2000)). According to Wagner's Law (1983), the Government's expenditure has certain influence on economic growth and investment attraction of the country.

Huang's research (2003), Braunstein \& Epstein (2002) showed that FDI can substitute capital for long periods DI. Research by Acar, Eris, \& Tekce (2012) in 13 countries in the Middle East and North Africa (MENA) over the period 1980-2008 demonstrated DI overwhelms FDI. According to Jadhav (2012), FDI has an impact on GDP, but the impact is less than the impact of exports on GDP.

Globerman \& Shapiro (2003) said that, the macro - economic factors including economic growth, inflation, balance of payments, foreign exchange rates, the transparency of the process and legal government, ... has an impact on the collection FDI into the country. Durham (2004), said that institutional and policy related to investment attraction of national decisions affecting FDI inflows to the country. According Yavan (2010) and Meyer \& Nguyen (2005), the volume of goods transported and the length of roads that affect FDI flows.

Demirhan \& Masca (2008) research in 38 developing countries from 2000 to 2004 the result shows that factors such as: market size (measured by GDP), infrastructure (represented by the number of telephone lines) and trade openness positive impact of FDI in these countries, inflation is low, FDI and tax increases. Azam (2010) said that the size of the market, official development assistance to the positive impact of FDI and inflation negative impact on FDI. Study Liu (2008) pointed out the cause of the FDI inflows into China's regions differ significantly due to the characteristics of each region.

Harris \& Reid (2010) using annual data base (ARD) to assess factors affecting FDI flow into the country of the business in Scotland and operating in foreign markets. The study results showed that the level of the workforce, exports and trade barriers have a strong influence on FDI inflows.

Nguyen Van Phuc and Nguyen Dai Hiep (2011) show, the variable component of PCI indicators such as total industrial products, legal institutions, infrastructure and business support services that affect the FDI in provinces/cities in Vietnam. According to the results of Senturk (2010) and Nguyen Minh Tien's (2014) reseach, the economic crisises in 1994 and 2008 did not affect FDI flows but the economic growth of the country. Countries with higher aperture economic have the greater ability to influence.

Khachoo \& Khan (2012) used estimation method by the econometric model (data sheet) identified factors affecting FDI inflows into developing countries in a long time (19822008). The study was based on a sample of 32 developing countries. The results showed that, the market size, total production, infrastructure and labor value are the determining factors in FDI flows into developing countries.

According to Nguyen Minh Tien (2014), budget revenues have a positive impact on economic growth (GDP) in the North but have a negative impact (negative effect) in the South and thereby affect FDI. At the same time, the authors also found no relationship between regular spending by the Government 
to FDI and GDP.

Solomon (2011) used GMM estimation method with a data table of 111 countries from 1981 to 2005 . The results showed that the level of economic development, human resources and quality of the political environment in the country have positive impacts on FDI and economic growth.

\section{Research model}

ln_ln_tongfdi $i_{i, t}$

$$
\begin{aligned}
& =\alpha+\beta_{1} * \text { ln_tongfdi }_{i, \mathrm{t}-1}+\beta_{2} * \ln \_g p d 1_{\mathrm{i}, \mathrm{t}-1}+\beta_{3} * \ln \_ \text {vonnn }_{\mathrm{i}, \mathrm{t}}+\beta_{4} \\
& *{\ln \_\operatorname{vontn}_{\mathrm{i}, \mathrm{t}}}+\beta_{5} * \operatorname{ldlv} \_\mathrm{ds}_{\mathrm{i}, \mathrm{t}}+\beta_{6} * \text { open }_{\mathrm{i}, \mathrm{t}}+\beta_{7} * \mathrm{cpi}_{\mathrm{i}, \mathrm{t}}+\beta_{8} * \ln \_ \text {banle }_{\mathrm{i}, \mathrm{t}} \\
& +\beta_{9} * \text { thuns_gdp }{ }_{\mathrm{i}, \mathrm{t}}+\beta_{10} * \mathrm{tx}_{-} g d p_{\mathrm{i}, \mathrm{t}}+\beta_{11} * \text { lvchh_b } \mathrm{b}_{\mathrm{i}, \mathrm{t}}+\beta_{12} * \text { lvchh_t } \mathrm{t}_{\mathrm{i}, \mathrm{t}} \\
& +\beta_{13} * \mathrm{cftt}_{\mathrm{i}, \mathrm{t}}+\beta_{14} * \operatorname{htdn}_{\mathrm{i}, \mathrm{t}}+\beta_{15} * \mathrm{khtc}+\mathrm{n}_{\mathrm{i}}+\mathrm{r}_{\mathrm{t}}+\mathrm{e}_{\mathrm{i}, \mathrm{t}}
\end{aligned}
$$

Với $\quad \mathrm{i}$ : Local represents $\mathrm{i} ; \mathrm{i}=1 ; 2 ; 3 ; 4 ; \ldots . . ; 13$

$\mathrm{t}$ : Year $\mathrm{t} ; \quad \mathrm{t}=1 ; 2 ; 3 ; 4(10$ year from 2005 to 2014$)$

\begin{tabular}{|c|c|c|c|c|c|}
\hline $\begin{array}{l}\text { Variable } \\
\text { content }\end{array}$ & Sign & Calculation & $\begin{array}{l}\text { Expecte } \\
\text { d sign }\end{array}$ & $\begin{array}{c}\text { Select the variable } \\
\text { base }\end{array}$ & $\begin{array}{l}\text { Group } \\
\text { proxied }\end{array}$ \\
\hline $\begin{array}{l}\text { Total FDI } \\
\text { (millions USD) }\end{array}$ & ln_tongFDI & $\begin{array}{l}\text { Total FDI (millions } \\
\text { USD) (neper } \\
\text { logarithm) }\end{array}$ & & $\begin{array}{l}\text { Keynes (1936), } \\
\text { Nguyen Minh Tien } \\
(2014)\end{array}$ & $\begin{array}{l}\text { Dependent } \\
\text { variable }\end{array}$ \\
\hline $\begin{array}{l}\text { Total FDI } \\
\text { (millions USD) } \\
\text { last year }\end{array}$ & ln_tongFDI L1 & $\begin{array}{l}\text { Total FDI (millions } \\
\text { USD) last year } \\
\text { (neper logarithm) }\end{array}$ & + & $\begin{array}{l}\text { Keynes (1936), } \\
\text { Nguyen Minh Tien } \\
(2014)\end{array}$ & $\begin{array}{l}\text { 1-year delay } \\
\text { of the } \\
\text { dependent } \\
\text { variable }\end{array}$ \\
\hline $\begin{array}{l}\text { GDP at constant } \\
\text { prices in } 2010 \\
\text { (billion VN } \\
\text { dong) }\end{array}$ & ln_GDP1 & $\begin{array}{l}\text { GDP at constant } \\
\text { prices in } 2010 \\
\text { (billion VN dong) } \\
\text { (neper logarithm) }\end{array}$ & + & $\begin{array}{l}\text { Keynes (1936), } \\
\text { Dunning (1981), } \\
\text { Globerman \& } \\
\text { Shaopiro (2003) }\end{array}$ & $\begin{array}{l}\text { Economic } \\
\text { growth }\end{array}$ \\
\hline $\begin{array}{l}\text { Total investment } \\
\text { of the state } \\
\text { (billion VN } \\
\text { dong) }\end{array}$ & ln_vonnn & $\begin{array}{l}\text { Total investment of } \\
\text { the state (logarit } \\
\text { Nêpe) }\end{array}$ & + & $\begin{array}{l}\text { Keynes (1936), } \\
\text { Nguyen Minh Tien } \\
(2014)\end{array}$ & \multirow{2}{*}{ Investment } \\
\hline $\begin{array}{l}\text { Total investment } \\
\text { of the domestic } \\
\text { private (billion } \\
\text { VN dong) }\end{array}$ & ln_vonnn & $\begin{array}{l}\text { Total investment of } \\
\text { the domestic private } \\
\text { (neper logarithm) }\end{array}$ & + & $\begin{array}{l}\text { Keynes (1936), } \\
\text { Nguyen Minh Tien } \\
(2014)\end{array}$ & \\
\hline $\begin{array}{l}\text { Percentage of } \\
\text { workers } \\
\text { working/ } \\
\text { population (\%) }\end{array}$ & ln_ldlv & $\begin{array}{l}\text { Percentage of } \\
\text { workers working/ } \\
\text { population }\end{array}$ & + & $\begin{array}{l}\text { Keynes (1936), } \\
\text { Solomon (2011) }\end{array}$ & $\begin{array}{l}\text { Human } \\
\text { Resources }\end{array}$ \\
\hline
\end{tabular}

u: Error $\quad \beta_{0}:$ Slope

$\beta_{1} \ldots{ }_{12}$ : Estimated coefficients of the independent variables.

Table 1. Description of the variables in the research model 


\begin{tabular}{|c|c|c|c|c|c|}
\hline $\begin{array}{l}\text { Variable } \\
\text { content }\end{array}$ & Sign & Calculation & $\begin{array}{l}\text { Expecte } \\
\text { d sign }\end{array}$ & $\begin{array}{c}\text { Select the variable } \\
\text { base }\end{array}$ & $\begin{array}{c}\text { Group } \\
\text { proxied }\end{array}$ \\
\hline $\begin{array}{l}\text { The openness of } \\
\text { the economy }\end{array}$ & open & $\begin{array}{l}\text { Total import and } \\
\text { export /GDP }\end{array}$ & + & $\begin{array}{l}\text { Keynes (1936), } \\
\text { Harris \& Teid } \\
(2010)\end{array}$ & \multirow{3}{*}{ Market } \\
\hline $\begin{array}{l}\text { Consumer price } \\
\text { index }(\%)\end{array}$ & cpi & $\begin{array}{l}\text { Consumer price } \\
\text { index }\end{array}$ & - & $\begin{array}{l}\text { Keynes (1936), } \\
\text { Nguyen Minh Tien } \\
(2014)\end{array}$ & \\
\hline $\begin{array}{l}\text { The total value } \\
\text { of retail sales } \\
\text { (billion VN } \\
\text { dong) }\end{array}$ & ln_banle & $\begin{array}{l}\text { The total value of } \\
\text { retail sales (neper } \\
\text { logarithm) }\end{array}$ & + & $\begin{array}{l}\text { Heckscher và Ohlin } \\
(1991), \text { Khachoo và } \\
\text { Khan (2012), Okafor } \\
(2015)\end{array}$ & \\
\hline $\begin{array}{l}\text { Budget revenue } \\
\text { /GDP }(\%)\end{array}$ & thuns_gdp & $\begin{array}{l}\text { Budget revenue } \\
\text { /GDP }(\%)\end{array}$ & + & $\begin{array}{l}\text { Wagner (1983), } \\
\text { Nguyen Minh Tien } \\
(2014)\end{array}$ & \multirow{4}{*}{$\begin{array}{c}\text { Features of } \\
\text { the local }\end{array}$} \\
\hline $\begin{array}{l}\text { Recurrent } \\
\text { expenditure } \\
\text { account in the } \\
\text { budget /GDP } \\
(\%)\end{array}$ & tx_gdp & $\begin{array}{l}\text { Recurrent } \\
\text { expenditure account } \\
\text { in the budget /GDP }\end{array}$ & + & $\begin{array}{l}\text { Wagner (1983), } \\
\text { Nguyen Minh Tien } \\
(2014)\end{array}$ & \\
\hline $\begin{array}{l}\text { The cost to enter } \\
\text { the market } \\
\text { (point) }\end{array}$ & $\mathrm{cftt}$ & $\begin{array}{l}\text { The cost to enter the } \\
\text { market (components } \\
\text { of the PCI scores) }\end{array}$ & + & $\begin{array}{l}\text { Dunning (1981), } \\
\text { Nguyen Van Phuc \& } \\
\text { Nguyen Dai Hiep } \\
\text { (2011) }\end{array}$ & \\
\hline $\begin{array}{l}\text { Economic } \\
\text { development } \\
\text { policies of } \\
\text { private (point) }\end{array}$ & htdn & $\begin{array}{l}\text { Economic } \\
\text { development policies } \\
\text { of private } \\
\text { (components of the } \\
\text { PCI scores) }\end{array}$ & + & $\begin{array}{l}\text { Dunning (1981), } \\
\text { Nguyen Van Phuc \& } \\
\text { Nguyen Dai Hiep } \\
\text { (2011) }\end{array}$ & \\
\hline $\begin{array}{l}\text { Transportation } \\
\text { of cargo by } \\
\text { waterway } \\
\text { (thousand tonnes } \\
\text { / km) }\end{array}$ & lvchh_b & $\begin{array}{l}\text { Transportation of } \\
\text { cargo by road (neper } \\
\text { logarithm) }\end{array}$ & + & $\begin{array}{l}\text { Dunning (1981), } \\
\text { Meyer \& Nguyen } \\
\text { (2005), Liu (2008) }\end{array}$ & \multirow{2}{*}{$\begin{array}{c}\text { The } \\
\text { infrastructure }\end{array}$} \\
\hline $\begin{array}{l}\text { Transportation } \\
\text { of cargo by } \\
\text { waterway } \\
\text { (thousand tonnes } \\
/ \mathrm{km})\end{array}$ & lvchh_t & $\begin{array}{l}\text { Transportation of } \\
\text { cargo by waterway } \\
\text { (neper logarithm) }\end{array}$ & + & $\begin{array}{l}\text { Dunning (1981), } \\
\text { Meyer \& Nguyen } \\
\text { (2005), Liu (2008) }\end{array}$ & \\
\hline $\begin{array}{l}\text { The global } \\
\text { financial crisis }\end{array}$ & khkt & $\begin{array}{l}\text { Dummy variable } \\
\text { (value }=0 \text { when } \\
\text { receiving since } 2009 \\
\text { or earlier, the value }= \\
1 \text { from } 2010 \text { to } 2014 \text { ) }\end{array}$ & - & $\begin{array}{l}\text { Senturk (2010), } \\
\text { Nguyen Minh Tien } \\
(2014)\end{array}$ & $\begin{array}{l}\text { The impact } \\
\text { of the } \\
\text { external } \\
\text { economy }\end{array}$ \\
\hline
\end{tabular}




\section{Research data and the method of data analysis}

Subjects and research limitation: FDI has invested in the Mekong Delta (13 provinces/cities) in long period of 10 years (2005-2014). The data collected from Statistics Yearbook of PSO in 13 provinces in Mekong Delta and the results evaluated Provincial Competitiveness Index (PCI) of the 13 provinces in 10 years (collected from electronic information page at VCCI: www.vcci.com.vn). The number of 130 valids observations.

The study used regression of Arellano \& Bond GMM (1991) because the method used to test the correlation itself, overcomed the endogenous variables in the model of latency. According to Judson \& Owen (1997), GMM model has 2 basic testing is testing Sargan Hansen and serial correlation test. The first differences chain 1 (the phenomenon of error autocorrelation level 1 - AR1) often violated so often dismissed the hypothesis $\mathrm{H}_{0}\left(\mathrm{H}_{0}\right.$ : no autocorrelation phenomena). Thus, the different chain level 2 (the phenomenon of error autocorrelation level 2 - AR2) is more important because it tested autocorrelation phenomena at higher levels. Results serial correlation test AR (2) if there are prob. $\geq$ 0.05 means no correlation phenomena in the model chain. Accreditation Sargan - Hansen
Prob $>$ chi $2 \geq 0.05$ means that the effects of endogenous variables were removed and removal of defects, estimating model is consistent.

\section{Research results}

\subsection{Descriptive statistical analysis}

Mekong Delta region's average GDP value is not high. The highest value of this area has 68,536 billion VND. GDP value in 10 years (2005-2014) of the whole Mekong Delta region is $27,019.75$ billion VND. This is a very small figure. In some years, FDI in the Mekong Delta region equaled zero (no investment - this is the lowest level). The highest capital was in 2014 which was 6,636 million USD, the average of 13 provinces / cities in the period 2005 to 2014 is 658.84 million USD. This figure is relatively small compared to the total volume of FDI inflows into Vietnam. An average of 10 years, the total investment in the country in the Mekong Delta reached 9,240.74 billion VND, of which, of private investment in the country has reached more than 6,000 billion VND, remaining more than 3,000 billion VND is capital state's investment. Thus, the Mekong Delta, the private investment of capital in the country is mainly in the economy. Private investment capital in the country's Mekong Delta region has the lowest value of 78 billion VND, the highest was 23,048 billion VND.

Table 2. Results of descriptive statistics of variables in the research model

\begin{tabular}{|l|c|c|c|c|}
\hline \multicolumn{1}{|c|}{ Variable } & Minimum & Maximum & Mean & $\begin{array}{c}\text { Std. } \\
\text { Deviation }\end{array}$ \\
\hline $\begin{array}{l}\text { GDP at constant prices in 2010 } \\
\text { (billion VND) }\end{array}$ & 7,836 & 68,536 & $27,019.75$ & $13,864.84$ \\
\hline Total FDI (millions USD) & 0 & 6,636 & 658.84 & $1,251.64$ \\
\hline $\begin{array}{l}\text { Total investment of the } \\
\text { domestic private (billion VND) }\end{array}$ & 78 & 23,048 & $6,043.65$ & $4,587.04$ \\
\hline $\begin{array}{l}\text { Total investment of the state } \\
\text { (billion VND) }\end{array}$ & 266 & 14,246 & $3,197.09$ & $3,119.45$ \\
\hline
\end{tabular}




\begin{tabular}{|l|c|c|c|c|}
\hline \multicolumn{1}{|c|}{ Variable } & Minimum & Maximum & Mean & $\begin{array}{c}\text { Std. } \\
\text { Deviation }\end{array}$ \\
\hline $\begin{array}{l}\text { Percentage of workers working/ } \\
\text { population (\%) }\end{array}$ & 45.73 & 61.908 & 55.750 & 3.284 \\
\hline The openness of the economy & 0.59 & 11.390 & 2.648 & 1.961 \\
\hline Consumer price index (\%) & 99.31 & 128.160 & 108.340 & 5.967 \\
\hline Budget revenue /GDP (\%) & 10.15 & 24.15 & 16.23 & 22.57 \\
\hline $\begin{array}{l}\text { Recurrent expenditure account } \\
\text { in the budget /GDP (\%) }\end{array}$ & 3.50 & 23.39 & 9.23 & 3.93 \\
\hline $\begin{array}{l}\text { The total value of retail sales } \\
\text { (billion VND) }\end{array}$ & $2,664.08$ & 49.559 .26 & $19,470.07$ & $11,755.08$ \\
\hline $\begin{array}{l}\text { Transportation of cargo by } \\
\text { road(thousand tonnes/km) }\end{array}$ & 154.00 & $7,009.00$ & $2,246.05$ & $1,532.23$ \\
\hline $\begin{array}{l}\text { Transportation of cargo by } \\
\text { waterway (thousand tonnes/km) }\end{array}$ & 339.00 & $19,075.00$ & $4,756.69$ & 4.128 .93 \\
\hline $\begin{array}{l}\text { The cost to enter the market } \\
\text { (point) }\end{array}$ & 4.53 & 9.54 & 7.93 & 1.02 \\
\hline $\begin{array}{l}\text { Economic development policies } \\
\text { of private (point) }\end{array}$ & 1.40 & 8,68 & 4,70 & 1.32 \\
\hline World financial crisis (dummy) & 0 & 1 & 0.50 & 0.50 \\
\hline Sample = 130 observations & & & & \\
\hline
\end{tabular}

Average period 2005 - 2014, the percentage of workers working/population was $45.73 \%$ (lowest), the highest is nearly $62 \%$, over $55 \%$ of the average. This data shows that the labor force is the advantage of the Mekong Delta because labor is an essential inputs and the importance of all economic activity. The exports and imports of many local and should not open the economy hit a pretty average. In fact, the city/Mekong Delta are mainly exported aquaculture commodities (rice, fish fillets, shrimp, fish,...) should not high export value. In contrast, the Mekong Delta provinces import a lot of machinery and equipment, aquaculture feed, inputs ... This situation should improve both the export and import direction.

Consumer price index $(\mathrm{CPI})$ in the Mekong Delta is not much volatility compared with the national average, the
Mekong Delta's average in the period from 2005 to 2014, consumer price index was at an average of $108.34 \%$, the highest level was also $128.16 \%$. Thus, the region CPI compared with the national average tends to be lower.

Budget revenue/GDP across the Mekong Delta is in 10-years period (2005-2010) to top at $24.15 \%$, which is the lowest (just over $10 \%)$. Meanwhile, the proportion of recurrent expenditure/GDP ratio to $23: 39 \%$, the average recurrent expenditure accounted for over 9\%/GDP. This result shows that at its peak, the Mekong Delta percentage of revenue/GDP nearly equals to the expenditure/GDP. This is a sign that, with the Mekong Delta situation is not high budget revenues, revenues were offset mainly recurrent expenditure.

The total retail value of the Mekong Delta region has the lowest value in the period 2005 - 2014 was 2,664.08 billion, the highest level 
can only 49.559 .26 billion and average value of about 19,470.07 billion. The value of retail sales suggests the Mekong Delta region, the regional economy has not really developed, the level of consumer goods and services is still low.

Considering the average of the Mekong Delta in the period 2005 - 2014, the volume of goods transported by ship is two times higher than the volume of goods transported by road. The volume of freight by ship ups to 19.075 highest thousand tons, while the volume of goods transported by road reaches the highest level with only 7.009 thousand tons. This result shows that the goods transported in the Mekong Delta or to other areas mainly by rivers.

The cost to enter the market and economic development policies are two variants private component of the index PCI. According to statistical results (table 2) shows, the cost of entering the market has averaged nearly 8 points points and economic development policies with a GPA privatization under 5 points. Thus, companies not appreciate "economic development policy privatization" of the locality. This may well be one of the reasons for private enterprises and foreign invested less in this area.

\subsection{Test correlation matrix and} multicollinearity

Gujarati (2009) argues that there are two commonly used signs to identify signs of multicollinearity between the variables in the model is to use the correlation coefficient pair and VIF. The correlation coefficient pair (pairwise correlation) between the independent variables and coefficients greater than 0.85 greater than 10 is VIF multicollinearity occurs between variables.

According to the results of correlation analysis (table 3) shows, the variable "ln_banle" correlation coefficient of about 0.78 to the variable "In_gdp1" and turn "lvchh_t" correlation coefficient of 0.77 with variable also about " lvchh_b ". Thus, these variables are correlated with each other tightly. However, when considering VIF coefficients (table 3) we can see, the largest VIF coefficients of the variables only 5.78. Thus, variations in the pattern of FDI no multicollinearity phenomenon occurs. This allows the regression results in the appropriate next steps. 
Table 3. Inspection results multicollinearity and VIF

\begin{tabular}{|c|c|c|c|c|c|c|c|c|c|c|c|c|c|c|}
\hline Variable & ln_gdp1 & ln_vonnn & ln_vontn & ldlv_ds & open & cpi & thuns_gdp & tx_gdp & ln_banle & lvchh_b & lvchh_t & $\mathrm{cftt}$ & htdn & khkt \\
\hline ln_gdp1 & 1,00 & & & & & & & & & & & & & \\
\hline ln_vonnn & 0,74 & 1,00 & & & & & & & & & & & & \\
\hline ln_vontn & 0,72 & 0,72 & 1,00 & & & & & & & & & & & \\
\hline ldlv_ds & 0,18 & 0,02 & 0,15 & 1,00 & & & & & & & & & & \\
\hline open & 0,27 & 0,24 & 0,30 & - 0,05 & 1,00 & & & & & & & & & \\
\hline cpi & - 0,01 & 0,07 & 0,09 & 0,03 & 0,04 & 1,00 & & & & & & & & \\
\hline thuns_gdp & 0,65 & 0,39 & 0,55 & 0,25 & 0,47 & 0,00 & 1,00 & & & & & & & \\
\hline tx_gdp & 0,28 & 0,23 & 0,11 & 0,42 & 0,06 & - 0,18 & 0,30 & 1,00 & & & & & & \\
\hline ln_banle & 0,78 & 0,65 & 0,75 & 0,11 & 0,29 & 0,09 & 0,67 & 0,22 & 1,00 & & & & & \\
\hline lvchh_b & 0,31 & 0,06 & 0,22 & 0,23 & - $\quad 0,01$ & 0,04 & 0,24 & - 0,09 & 0,24 & 1,00 & & & & \\
\hline lvchh_t & 0,31 & 0,03 & 0,33 & 0,31 & 0,04 & $-0,00$ & 0,38 & $-0,13$ & 0,35 & 0,77 & 1,00 & & & \\
\hline $\mathrm{cftt}$ & 0,38 & 0,39 & 0,41 & 0,38 & 0,11 & 0,04 & 0,31 & 0,33 & 0,36 & 0,19 & 0,172 & 1,00 & & \\
\hline htdn & 0,04 & 0,01 & 0,04 & $-0,13$ & 0,02 & $-0,23$ & 0,03 & $-0,20$ & 0,12 & 0,05 & 0,169 & $-0,249$ & 1,00 & \\
\hline khkt & $-0,74$ & 0,53 & $-0,52$ & $-0,39$ & $-0,19$ & $-0,07$ & 0,62 & $-0,61$ & 0,63 & $-0,21$ & $-0,235$ & $-0,250$ & 0,08 & 1,00 \\
\hline VIF & 5.78 & 3.68 & 3.58 & 1.88 & 1.40 & 1.35 & 2.98 & 3.06 & 3.96 & 2.84 & 3.75 & 1.92 & 1.31 & 5.31 \\
\hline
\end{tabular}




\subsection{Regression analysis results}

Inspections of endogenous and autocorrelation are through accreditation Sagan (Sagan test), which has acceptable results $\mathrm{H}_{0}$ hypothesis $\left(\mathrm{H}_{0}\right.$ : exogenous variables). Through testing the AR (2) - the phenomenon of error autocorrelation level 2 (higher) for $\operatorname{Pr}>\mathrm{z}=0.713$ (greater than 0.05) showed no autocorrelation phenomenon (hypothesis - $\mathrm{H}_{0}$ : no autocorrelation phenomena). Sagan simultaneously testing outside groups (excluding Sargan test group) for the tool level (GMM instruments for levels) results in Prob> chi2 are greater than 0.05 . Thus, instrumental variables in the model are appropriate.

Table 4. Results of regression GMM

\begin{tabular}{|c|c|c|c|}
\hline Variables & Coef. & Std. Err. & $\mathrm{P}>|\mathrm{z}|$ \\
\hline ln_tongfdi L1. & $0,244 * * *$ & 0,092 & 0,008 \\
\hline ln_gdp1 & $0,048 * *$ & 0,023 & 0,035 \\
\hline ln_vonnn & $1,467 * * *$ & 0,341 & 0,000 \\
\hline ln_vontn & $-0,029$ & 0,341 & 0,932 \\
\hline ldlv_ds & $15,610 * *$ & 6,587 & 0,018 \\
\hline open & $0,171^{*}$ & 0,094 & 0,070 \\
\hline cpi & $-0,007$ & 0,0275 & 0,806 \\
\hline thuns_gdp & $-0,0008$ & 0,0006 & 0,192 \\
\hline tx_gdp & $-0,122 *$ & 0,064 & 0,056 \\
\hline ln_banle & $-2,361 * * *$ & 0,4644 & 0,000 \\
\hline lvchh_b & $0,564^{* *}$ & 0,282 & 0,045 \\
\hline lvchh_t & $0,637 * * *$ & 0,326 & 0,051 \\
\hline $\mathrm{cftt}$ & 0,170 & 0,192 & 0,376 \\
\hline htdn & 0,1229 & 0,119 & 0,303 \\
\hline khkt & $-0,211$ & 0,636 & 0,740 \\
\hline \multicolumn{2}{|l|}{ observers } & \multicolumn{2}{|c|}{117} \\
\hline \multicolumn{2}{|c|}{ Sargan test of overid. restrictions } & \multicolumn{2}{|c|}{ Prob $>$ chi $2=0,570$} \\
\hline \multicolumn{2}{|c|}{ Sargan test excluding group } & \multicolumn{2}{|c|}{ Prob $>$ chi $2=0,374$} \\
\hline \multicolumn{2}{|c|}{ Sargan test excluding group } & \multicolumn{2}{|c|}{ Prob $>$ chi $2=0,442$} \\
\hline \multicolumn{2}{|c|}{ Arellano-Bond test for $\mathrm{AR}(2)$} & \multicolumn{2}{|c|}{$\operatorname{Pr}>z=0,713$} \\
\hline
\end{tabular}

Many variables affect FDI flows into the Mekong Delta are: last year FDI (FDI latency 1 - ln_tongfdi L1), the growth of the local economy (ln_gdp1), government capital (ln_vonnn), ratio labor force working/population (ldlv_ds), the openness of the economy (open), the proportion of recurrent expenditure/GDP (tx_gdp), the total value of retail goods (ln_banle), mass transport goods on land (lvchh_b) and the 
volume of research used by water (lvchh_t). In 9 statistically significant variables, 7 variables impacts on FDI flows (ln_tongfdi) of Mekong Delta positively, two variables: The rate of recurrent expenditure/GDP (tx_gdp) and the total value of goods sold retail (ln_banle) negative impact on FDI inflows. Research results largely in line with initial expectations seal (subtracts total retail value) and in accordance with the actual situation in the provinces. Other variables: CPI, thuns_gdp, cftt, htdn have not found evidence of impact on FDI flows (ln_tongfdi) in the Mekong Delta.

\subsection{Discussion about Research results}

- FDI last year (ln_tongfdi L1): Statistically significant at $1 \%$, FDI last year had a positive impact on FDI inflows next year. Results in line with initial expectations and results of Nguyen Minh Tien (2014). Latency of FDI have cascading effects (positive impact) to the capital next year. This shows that localities attract FDI investment in FDI this year, it invested more in the following year will be higher. Current investment capital will be a gravity capital investment in the future.

- Economic growth (ln_gdp1): GDP variables that affect attracting FDI into the Mekong Delta at a statistically significant level of $5 \%$. This result is consistent with previous studies of: Globerman \& Shapiro (2003), Demirhan and Masca (2008), Nguyen Minh Tien (2014). According to the theory of the relationship between FDI and GDP NowBhissum (2009), FDI and GDP impact response, meaning that GDP has an impact on FDI and vice versa, this is true for case studies in the Mekong Delta.

- Govement capital (ln_vonnn): Invested by the state investment in the Mekong Delta as much greater impact on attracting FDI into the region as evidenced by these two variables have a positive impact (in accordance initial expectations) together (at the ie $1 \%$ ). The study results are consistent with several previous studies of Acar et al. (2012) and Nguyen Minh Tien (2014). Govement capital is essential for the overall development of the country and of the city/Mekong Delta and influences in attracting FDI which is appropriate.

- The labor force is working/population (ldlv_ds): The labor force is working / population is an important factor which is contributing to the economic growth and has an impact on attracting foreign investment. Workforce has a positive impact on FDI (right expectations original seal, with a significance level of 5\%). The study results fit with previous studies of Nguyen Minh Tien (2014) and Solomom (2011). Labour inputs are indispensable to any economic background. Thus, the labor force has affected investment decisions of FDI enterprises is consistent.

- The openness of the economy (open): Economic openness is positive impact of FDI (10\% significance level). Findings consistent with initial expectations and marks consistent with research results: Demirhan and Masca (2008), Harris and Teid (2010), Nguyen Minh Tien (2014). According to the theory of the market size of the Balassa (1966), international economic theory $\mathrm{H}$ - $\mathrm{O}$, foreign investors often have the choice of investing a large market size, reducing trade barriers health, where investments are low cost, ... the open economy increases toward increasing exports will benefit the local authorities in the process of attracting FDI.

- Regular budget expenditures/GDP (tx_gdp): The total regular budget expenditure/GDP is a variation on fiscal policy. This variable expected negative impact on FDI inflows. Results correct initial expectations and consistent with findings of Nguyen Minh Tien (2014). Mekong Delta sizeable recurrent expenditure while capital expenditures grow smaller, so more frequently when spending while revenues have not led to 
a situation many localities collected only needs regular expenditure, no account the budget for development investment, so investors will not invest in the match.

- Total value of retail goods (ln_banle): According to the results of the regression analysis, these variable effects mixed with FDI inflows (statistically significant at $1 \%$ ), the results are contrary to initial expectations. In previous studies, the results are not consistent, namely: study Khachoo and Khan (2012) shows that the market size does not affect FDI inflows; Okafor (2015) suggested that foreign investors do not pay much attention to power consumption in the market of investment-receiving country for foreign investors mainly consumed in the form of exports to the markets of countries other. The study results fit with the reality, because the market really Mekong Delta is not the largest market, attracting foreign investment. Foreign investment in the Mekong Delta because of the other advantages of the region.

- Transportation of goods by road (lvchh_b): In the study by Mayer $\&$ Nguyen (2005), the volume of goods transported by road to the positive impact of FDI. This study also showed that the volume of goods transported on land (infrastructure represents local) has a positive impact on FDI inflows into the city/province (statistical significance level of $5 \%$ ). Road infrastructure, landing transport remain the concern of investors.

- Transportation of cargo by waterway (lvchh_t): Transportation of cargo by waterway had a positive impact on FDI inflows into the city/MD (statistically significant at 10\%). The result is true with initial expectations and in line with research by Mayer and Nguyen (2005). According to Dunning (1981), foreign investors are interested in the advantages of geographic location (resources, the integrity of the infrastructure, the development of infrastructure, ...) when it comes to investment

\section{Conclusion and Recommendations}

\subsection{Conclusion}

Based on 130 observations in 13 provinces/cities of the Mekong Delta, by GMM regression methods, research has found FDI in the province/city of the Mekong Delta region affected by $9 / 15$ independent variables, namely: FDI last year, economic growth (GDP), the state capital, the labor force is working/population, the openness of the economy, the rate of recurrent expenditure/GDP, the volume of transport cargo by road, freight volume by water, and the total value of retail goods. In 9 statistically significant variable, 7 variable positive impact on FDI inflows into the city/MD, two variable proportions of recurrent expenditure/GDP and total retail value is the negative impact to the line FDI.

In particular, the study results also found, the principal representative of the infrastructure according to local characteristics, such as freight volumes by road and freight volume by water impacts FDI in the Mekong Delta.

\subsection{Recommendations}

Provincial governments/city of the Mekong Delta attention specific characteristics and advantages of the locality as freight by road and by water when doing the promotion, calling for foreign investment. Dubbed the Mekong Delta River area, river systems are developed so shipping is the advantage of the Mekong Delta. This is to promote the process of economic development planning as well as calling for the Mekong Delta investment. On the reality show, the Mekong Delta waterways infrastructure and unfinished road, need tobe completed in order to attract foreign investors to invest capital into the Mekong Delta. Government should increase the amount of state investment in infrastructure in Mekong Delta.

Mekong Delta has this advantage, the economic growth in the of period (2005 - 
2014) is quite high, and higher than the average national economic growth. This is an advantage in the process of attracting FDI in the Mekong Delta, it should be strengthened and promoted. The Mekong Delta has abundant labor force is an advantage for attracting FDI. However, the level of employment is limited, so training needs, improve the level and quality of the labor force to meet the needs of the business.
In Mekong Delta, if the government wants to attract more FDI in the future, they must reduce recurrent expenditure. Increased openness of the economy to create the conditions for business, receptive state of scientific proficiency, technical and modern management methods, the effectiveness of and manipulate the world's environment into a flexible MD dynamic, adjusted as necessary.

\section{REFERENCES}

Acar, S., Eris, B., \& Tekce, M. (2012). The effect of foreign direct investment on domestic investment: Evidence from MENA countries. Paper presented at the European Trade Study Group (ETSG) 14th Annual Conference, September, Leuven.

Arellano, M., \& Bond, S. (1991). Some tests of specification for panel data: Monte Carlo evidence and an application to employment equations. The review of economic studies, 58(2), 277-297.

Azam, M. (2010). Economic determinants of foreign direct investment in Armenia, Kyrgyz Republic and Turkmenistan: theory and evidence. Eurasian Journal of Business and Economics, 3(6), 27-40.

Braunstein, E., \& Epstein, G. (2002). Bargaining power and foreign direct investment in China: Can 1.3 billion consumers tame the multinationals?

Büthe, T., \& Milner, H. V. (2008). The politics of foreign direct investment into developing countries: increasing FDI through international trade agreements? American Journal of Political Science, 52(4), 741-762.

Demirhan, E., \& Masca, M. (2008). Determinants of foreign direct investment flows to developing countries: a cross-sectional analysis. Prague economic papers, 4(2008), 356-369.

Dunning, J. H. (1981). Explaining the international direct investment position of countries: towards a dynamic or developmental approach. Weltwirtschaftliches Archiv, 117(1), $30-64$.

Durham, J. B. (2004). Absorptive capacity and the effects of foreign direct investment and equity foreign portfolio investment on economic growth. European economic review, 48(2), 285-306.

Ghura, D., \& Goodwin, B. (2000). Determinants of private investment: A cross-regional empirical investigation. Applied Economics, 32(14), 1819-1829.

Globerman, S., \& Shapiro, D. (2003). Governance infrastructure and US foreign direct investment. Journal of International Business Studies, 34(1), 19-39.

Gujarati, D. N. (2009). Basic econometrics: Tata McGraw-Hill Education. 
Harris, R. I., \& Reid, R. S. (2010). The role of knowledge in Lowering Barriers to Internationalisation: Discussion Paper, 1-33.

Heckscher, E. F., \& Ohlin, B. G. (1991). Heckscher-Ohlin trade theory: The MIT Press.

Huang, Y. (2003). One country, two systems: Foreign-invested enterprises and domestic firms in China. China Economic Review, 14(4), 404-416.

Jadhav, P. (2012). Determinants of foreign direct investment in BRICS economies: Analysis of economic, institutional and political factor. Procedia-Social and Behavioral Sciences, 37, 5-14.

Judson, R. A., \& Owen, A. L. (1997). Estimating Dynamic Panel Data Models: A Practical Guide.

Keynes, J. M. (1936). Allgemeine Theorie der Beschäftigung, des Zinses und des Geldes (Vol. 6): Berlin.

Kojima, K. (1973). A macroeconomic approach to foreign direct investment. Hitotsubashi Journal of Economics, 14(1), 1-21.

Kojima, K. (2010). Direct Foreign Investment: A Japanese Model of Multi-national Business Operations: Routledge.

Khachoo, A. Q., \& Khan, M. I. (2012). Determinants of FDI inflows to developing countries: A panel data analysis.

Lipsey, R. E. (2001). Foreign direct investment and the operations of multinational firms: Concepts, history, and data: National Bureau of Economic Research.

Liu, Z. (2008). Foreign direct investment and technology spillovers: Theory and evidence. Journal of Development Economics, 85(1), 176-193.

Meyer, K. E., \& Nguyen, H. V. (2005). Foreign Investment Strategies and Sub-national Institutions in Emerging Markets: Evidence from Vietnam*. Journal of management studies, 42(1), 63-93.

Nowbutsing, B. (2009). FDI, domestic investment and economic growth: A theoretical framework.

Oshikoya, T. W. (1994). Macroeconomic determinants of domestic private investment in Africa: An empirical analysis. Economic development and cultural change, 42(3), 573-596.

Senturk, S. S. (2010). Total Factor Productivity Growth in Turkish Manufacturing Industries: A Malmquist Productivity Index Approach. Master of Science Thesis. Royal Institute of Technology, School of Architecture and the Built Environment.

Solomon, E. M. (2011). Foreign direct investment, host country factors and economic growth. Ensayos Revista de Economia, 30(1), 41-70.

Vu, T. B. (2008). Foreign direct investment and endogenous growth in Vietnam. Applied Economics, 40(9), 1165-1173.

Wagner, R. E. (1983). Public finance: Revenues and expenditures in a democratic society: Boston; Toronto: Little, Brown. 
Yavan, N. (2010). The location choice of foreign direct investment within Turkey: An empirical analysis. European Planning Studies, 18(10), 1675-1705.

The Ministry of Planning and Investment (2013). Conference Proceedings Summary 25 years to attract foreign direct investment in Vietnam, Hanoi. 2013 download at: fia.mpi.gov.vn

Nguyen Minh Sang (2011). Location, role, potential and strengths of economic in the Mekong Delta, Local Economic Department and Territory-Ministry of Planning and Investment, view: http://www.vietrade.gov.vn/vung-kinh-te-trong-diem-dbscl

Nguyen Minh Tien (2014). Foreign direct investment and economic growth in the regions of Vietnam, doctoral thesis in Economics, University of Economics Ho Chi Minh City. Ho Chi Minh.

Nguyen Van Phuc and Nguyen University Association (2011). Factors affecting foreign investment attracted by the provinces/cities in Vietnam: A cross-analysis of data, Scientific journal Open City University. Ho Chi Minh City, No. 02 (20) 2011, page 9 -19.

UNCTAD (2014). World Investment Report (WIR) of UNCTAD dated 06.24.2014 của UNCTAD, Newyork và Geneva. 